\author{
加藤 尚志 ${ }^{1}$, 鮑 新 努 $^{1}$, 鈴木 彰子 $^{1}$, 井原 俊英*1
}

\section{1 緒言}

アミノ酸は, 生体の最も基本的な構成成分であるととも に重要な生理活性物質であり, 生体に必須な栄養素の一つ である，そのため，アミノ酸含有量は様々な分野で測定さ れているが，クロマトグラフィーなどを利用して分析を行 う場合には, 分析対象成分の標準液を用いて検量線を作成 する必要がある，近年，健康志向の高まりによる特定のア ミノ酸成分が強化された機能性食品の普及や, 人の血液や 尿中のアミノ酸含有量のモニタリングによる発がんリスク の早期診断法への利用 ${ }^{1}$ など, アミノ酸分析の適用範囲が 拡大している. 併せて, その分析結果に精確さが求められ るようになってきており，多様なアミノ酸類を成分とする 計量トレーサビリティが確保された混合標準液を求める声 は大きくなっている21.

計量トレーサビリティの保証された混合標準液の調製に は, 国際単位系（SI）にトレーサブルな形で純度が決定さ れた標準物質と, 同様にSIにトレーサブルな分銅により校 正された天びんによる精密な計量が必要である. しかし, 本稿で対象とするアミノ酸類の一部は高い吸湿性をもつこ とが経験的に知られており, 取り扱い環境によっては天び んの計量值への影響が予想される。 それにもかかわらず, アミノ酸類の吸湿性に関する定量的なデー夕はこれまでほ とんど報告されておらず，取り扱い環境は経験的に設定さ れてきた。

そこで, 著者らは湿度制御機能を持つ熱重量測定装置を 用いて, 湿度変化に対するアミノ酸類の質量変動を測定 し, これらのアミノ酸類を安定に計量する環境条件を定量 的なデータから決定した. 本稿では, 41 種類の生体関連ア ミノ酸類に関する吸湿性及び昇華性の評価方法と，その結 果から決定したアミノ酸類の取り扱い環境について報告す ると共にアミノ酸混合標準液を作成する上で，より安定し た計量が可能な化学形態についても検討を行った.

\footnotetext{
* E-mail : t.ihara@aist.go.jp

${ }^{1}$ 産業技術総合研究所物質計測標準研究部門 : 305-8563 茨城県 つくば市梅園 1-1-1 つくば中央第 3
}

2 実験

\section{$2 \cdot 1$ 装置及び試薬}

質量変動の測定には湿度制御機能付き熱重量測定装置 Q5000SA（ティー・エー・インスッルメント製）を用いた. 本装置が持つ天びんの最小表示桁は $0.1 \mu \mathrm{g}$, 質量分解能は $0.01 \mu \mathrm{g}$ である. また, ペルチェ素子を用いた温度制御によ る等温安定性は $0.1{ }^{\circ} \mathrm{C}$ であり, 等温状態に扔ける湿度安定 性は土0.06\%である.

対象とした 41 種類の生体関連アミノ酸類の名称と略号 の一覧を Table 1 に示す. タンパク質性アミノ酸など 19 種 類については, 産業技術総合研究所が頒布する認証標準物 質である $\mathrm{NMIJ} \mathrm{CRM}^{3)}$ を用いた。 その他，非タンパク質性 アミノ酸を中心とした 22 種類のアミノ酸類は和光純薬工 業製の標準物質を用いた.

\section{$2 \cdot 2$ 装置の校正}

湿度制御機能付き熱重量測定装置における温度の校正 は, JCSS（Japan Calibration Service System）校正済の温度 計 THERMOPORT 20 (チノー製) により $25^{\circ} \mathrm{C}$ で行った. また，湿度の校正は, 臭化ナトリウムの潮解点によって行 い， $\pm 1.2 \%$ 以内であることを確かめた．天びんにおける 計量值の校正は,JCSS 校正済の分銅を用いて行った.

\section{$2 \cdot 3$ 測定方法}

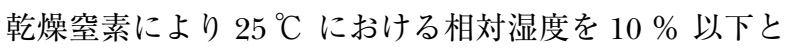
したグローブボックス内において，容量 $180 \mu \mathrm{L}$ の金属 コーティング石英パンに約 $5 \mathrm{mg}$ の試料をはかり取り, 速 やかに熱重量測定装置の測定チャンバー内に移した。測定 チャンバー内の温度は $25{ }^{\circ} \mathrm{C}$ とし, 実験室環境付近の湿度 (相対湿度 30〜 50\%,ただし吸湿性の高いアミノ酸類は相 対湿度 $0 \%$ ）から測定を開始した. 10 分間当たりの相対質 量変動が $0.01 \%$ 以下になった状態を平衡状態とし，この 時の測定值をその湿度における質量とした，各湿度での平 衡状態が達成されたところで相対湿度を $5 \%$ ずつ段階的 に上昇させながら，相対湿度 $80 \%$ まで操作した．さらに， 同様に平衡状態を達成させながら相対湿度を $5 \%$ ずつ段 階的に下降させ, 相対湿度 $0 \%$ まで操作する過程を 1 サイ 
Table 1 Critical relative humidity (CRH) of amino acids

\begin{tabular}{|c|c|c|c|}
\hline Compound & Abbreviation & CRH $(\%)$ & Reversibility \\
\hline L-Alanine & Ala & 80 & $\mathrm{R}$ \\
\hline L-Leucine & Leu & 80 & $\mathrm{R}$ \\
\hline Urea & Urea & 50 & $\mathrm{I}$ \\
\hline L-Isoleucine & Ile & 80 & $\mathrm{R}$ \\
\hline L-Phenylalanine & Phe & 80 & $\mathrm{R}$ \\
\hline L-Valine & Val & 80 & $\mathrm{R}$ \\
\hline L-Proline & Pro & 50 & I \\
\hline L-Arginine & Arg & 40 & I \\
\hline L-Lysine monohydrochloride & Lys & 50 & I \\
\hline L-Tyrosine & Tyr & 80 & $\mathrm{R}$ \\
\hline L-Threonine & Thr & 80 & $\mathrm{R}$ \\
\hline L-Serine & Ser & 80 & $\mathrm{R}$ \\
\hline Glysine & Gly & 80 & $\mathrm{R}$ \\
\hline L-Methionine & Met & 80 & $\mathrm{R}$ \\
\hline L-Histidine & His & 80 & $\mathrm{R}$ \\
\hline L-Cystine & Cys & 50 & I \\
\hline L-Glutamic acid & Glu & 80 & $\mathrm{R}$ \\
\hline L-Aspartic Acid & Asp & 80 & $\mathrm{R}$ \\
\hline Ammonium chloride & $\mathrm{NH}_{4}^{+}$ & 50 & $\mathrm{R}$ \\
\hline L-Glutamine & Gln & 80 & $\mathrm{R}$ \\
\hline L-Asparagine monohydrate & Asn & 80 & $\mathrm{R}$ \\
\hline$O$-Phospho-L-Serine & P-Ser & 80 & $\mathrm{R}$ \\
\hline Taurine & Tau & 80 & $\mathrm{R}$ \\
\hline$O$-Phosphoethanolamine & PEA & 80 & $\mathrm{R}$ \\
\hline L-Cystathionine & Ala-Hcy & 80 & $\mathrm{R}$ \\
\hline L-Hydroxyproline & Нyp & 80 & $\mathrm{R}$ \\
\hline Sarcosine & Sar & 50 & $\mathrm{I}$ \\
\hline L-2-Aminoadipic acid & Aad & 80 & $\mathrm{R}$ \\
\hline L-Citrulline & Cit & 80 & $\mathrm{R}$ \\
\hline DL-2-Aminobutyric acid & $\mathrm{Abu}$ & 80 & $\mathrm{R}$ \\
\hline$\beta$-Alanine & $\beta$ Ala & 50 & I \\
\hline DL-3-Aminoisobutyric acid monohydrate & bAbu & 80 & $\mathrm{R}$ \\
\hline 5-Hydroxy-DL-Lysine monohydrochloride & $5 \mathrm{Hyl}$ & 50 & $\mathrm{R}$ \\
\hline 4-Aminobutyric acid & $4 \mathrm{Abu}$ & 50 & $\mathrm{I}$ \\
\hline L-Ornitine monohydrochloride & Orn & 80 & $\mathrm{R}$ \\
\hline 2-Aminoethanol hydrochloride & $\mathrm{MEA} \cdot \mathrm{Cl}$ & 40 & $\mathrm{I}$ \\
\hline 1-Methyl-L-Histidine monohydrate & $1 \mathrm{MeHis} \cdot \mathrm{H}_{2} \mathrm{O}$ & 80 & $\mathrm{R}$ \\
\hline 3-Methyl-L-Histidine hydrate & $3 \mathrm{MeHis} \cdot 2 \mathrm{H}_{2} \mathrm{O}$ & 50 & $\mathrm{R}$ \\
\hline L-Carnosine & Car & 80 & $\mathrm{R}$ \\
\hline L-Tryptophan & $\operatorname{Trp}$ & 80 & $\mathrm{R}$ \\
\hline L-Anserine nitrate & Ans & 50 & $\mathrm{R}$ \\
\hline
\end{tabular}

クルとし， 計 4 サイクルの測定を行った.

\section{$2 \cdot 4$ 解析方法}

一例として, Met（略号は Table 1 参照）の測定結果を Fig. 1 に示す. 1 サイクル目の測定には試料中の揮発性不純 物などが影響する可能性があるため, 2 サイクル目以降の データを解析に用いた. 测定值について一次回帰分析を行 い, これにより得られた傾きから 1 時間あたりの質量減少 を求め, 昇華性の指標として用いた。 そのうえで, 傾き成 分を差し引いて補正した值を吸湿性由来の質量変動とし て, その最大值と最小值を求めた。 測定湿度範囲内での質 量の確率分布をこれらの間の一様分布とし, 最大值と最小 值の差を $2 \sqrt{3}$ で割った值を, 吸湿性による質量変動に伴 う標準不確かさ（以下, 吸湿性の不確かさ) として, 試料 の持つ吸湿性を表す指標とした。
計量トレーサビリティの確保された混合標準液は, 実用 性の観点から各成分の濃度の不確かさ $1 \%$ 以内を目標と しているため, 吸湿性の不確かさの許容值を $0.1 \%$ とし た。また，昇華性の影響による質量減少の許容值は，アミ ノ酸標準物質の計量操作に必要な時間なども考慮し, 一時 間あたり $0.2 \%$ と設定した。

相対湿度 0 〜 $80 \%$ のデータから得られた值が吸湿性の 不確かさの許容值を超えた場合には，除湿環境下での作業 を念頭に，相対湿度 0 〜 50 \% のデータについて再解析を 行った. それでも許容值を超えた場合は, さらに湿度変化 に伴う質量変動が許容值以下となる範囲まで上限湿度を $10 \%$ ずつ下げて範囲を狭めながら再解析を行い, 質量変 動が許容值以下となり, 十分安定なはかり取りが行えると 考えられる湿度範囲の上限を, 取扱い可能な臨界相対湿度 (CRH，\%）とした. 


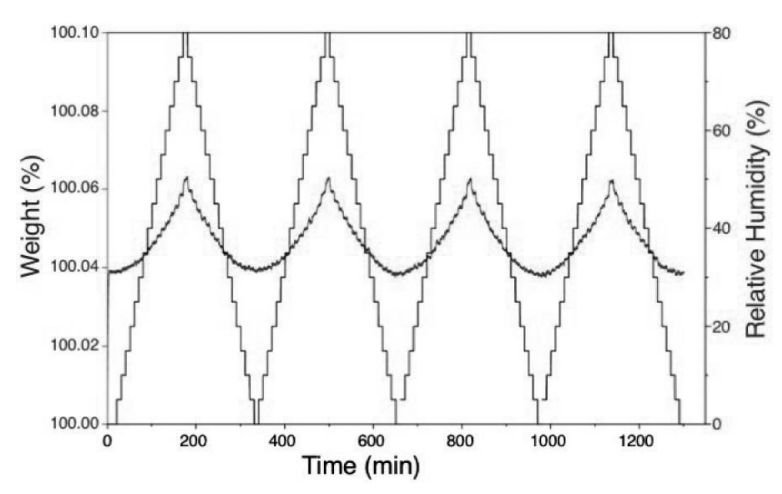

Fig. 1 Kinetics of the dynamic water sorptiondesorption of L-Methionine

\section{3 結果と考察}

\section{$3 \cdot 1$ アミノ酸類の昇華性評価}

ほぼすべての試料で一時間あたりの質量減少はしきい值 である一時間あたり $0.2 \%$ を十分に下回ったが, 2-アミノ エタノール (MEA) では一時間あたり $4.5 \%$ と大きく質量 が減少した。このため, アミノ酸混合標準液の成分とする ためには不適であると判断し塩酸塩である MEA・Clにつ いて検討を行った。 その結果, 一時間あたりの質量減少は $0.00033 \%$ と十分に小さい值が得られ, 化学形態によって 昇華性が大きく変化することを明らかとした．このため標 準液の調製に用いる標準物質としては MEA・Cl を用いる こととした.

\section{$3 \cdot 2$ 湿度変化に対して可逆的な質量変動が認められた}

\section{アミノ酸類}

$3 \cdot 2 \cdot 1$ 湿度変化に対して大きな質量変動が認められな いアミノ酸類 測定対象とした全 41 物質のうち 28 種類 のアミノ酸類では, 湿度の上昇に伴い緩やかに質量が増大 し, 湿度の下降に伴い吸湿時とほぼ同等の割合で質量が減 少していく様子が見られた. Metはその典型例（Fig. 1) で あり, 解析から相対湿度 0〜80\%における吸湿性の不確 かさ $0.0073 \%, 1$ 時間あたりの相対質量減少 $0.000031 \%$ が得られた. 他の 27 物質についても同等の解析結果が得 られたため, これらの物質は相対湿度 0 〜 $80 \%$ において 安定的なはかり取りが可能であると判断し，CRH を $80 \%$ とした.このように湿度変動が認められない, もしくは湿 度の増加に対し質量の増大などの変化を示すものの, 乾燥 雾囲気下に置かれることにより十分脱湿され, 可逆的に吸 湿前の質量に回復することができる物質を「可逆変化を示 す化合物（R）」として分類した（Table 1 参照）。なお, 本 研究で用いた 1-メチルヒスチジン（1MeHis）は定量 NMR 及び非水滴定法から得られた純度 ${ }^{4)}$ から計算される值から 1-メチルヒスチジン一水和物 $\left(1 \mathrm{MeHis} \cdot \mathrm{H}_{2} \mathrm{O}\right)$ であると推

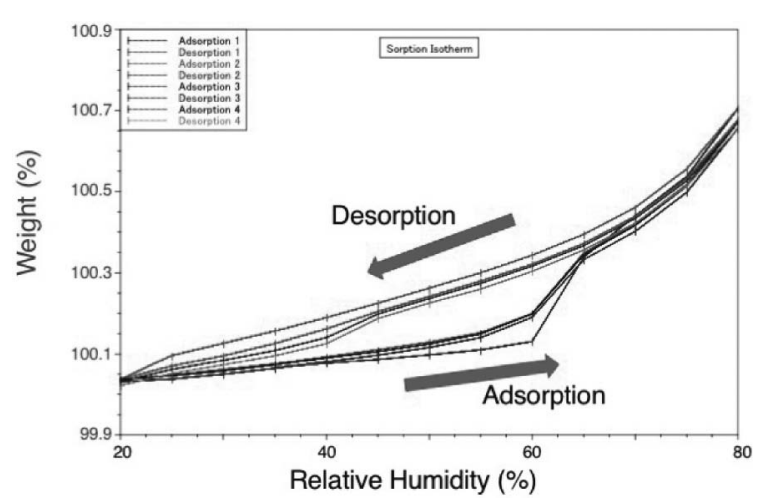

Fig. 2 Water sorption-desorption isotherm of 5-Hydroxy-DL-Lysine monohydrochloride, generated at $25{ }^{\circ} \mathrm{C}$, relative humidity $20 \%$ to $80 \%$, using $\mathrm{N}_{2}$ as a carrier gas

定される.

$3 \cdot 2 \cdot 2$ 湿度変化に対して特徵的な質量変動が認められ たアミノ酸類「可逆変化を示す化合物 $(\mathrm{R}) 」$ 」て分 類した物質群は, 湿度の増減に対して安定して変化を示 し，ある特定の湿度において再現性の高い質量を示す場合 が多かった. しかし，最終的に乾燥䨌囲気下に置くことで 吸湿前の質量に回復する物質でも, 湿度変化に対して特徴 的な質量変動が見られたいくつかの化合物があった。

その例として $5 \mathrm{Hyl}$ についての結果を Fig. 2 に示す. $5 \mathrm{Hyl}$ は, 湿度上昇時には相対湿度 $60 \%$ において大きく質量が 増大している。しかし, 湿度低下時には全体的に緩やかに 脱湿し，十分に元の質量まで脱湿され，同一の相対湿度で も吸湿時より脱湿時の方が大きな相対質量を持つことが確 認された. そのため, はかり取り作業時以外の保管時も含 めて, 何らかの原因で相対湿度 $60 \%$ 以上の環境に置かれ た場合には, 相対湿度 $20 \%$ 以下の環境で十分に乾燥させ なければ，安定した計量が行えなくなる可能性が考えられ た。 そこで，相対湿度の上限を 50 \% として再測定を行っ た結果を Fig. 3 に示す. 同一相対湿度における吸湿時と脱 湿時の質量の差は Fig. 2 よりも小さくなっており, 相対湿 度 $0 \sim 50 \%$ における吸湿性の不確かさもしきい值以内で あったことから，5Hylの CRH は $50 \%$ とした.

また, $\mathrm{NH}_{4}{ }^{+}$は相対湿度 $60 \%$ 程度までは相対湿度の増大 に対してほぼ一定の割合で相対質量が増減する様子が見ら れたが, 相対湿度 $75 \%$ において急激な質量の増大がおこ り, 全体の質量変動から得られる吸湿性の不確かさがしき い值を超えることになった。 しかし, 相対湿度 0 〜 $50 \%$ の 範囲内であれば，質量変動は十分に安定していたため CRH を50\%とした.

さらに,これらとは異なった挙動を示した例として 3 -メ チルヒスチジン (3MeHis) の質量変動プロファイルを Fig. 4 に示す. 測定開始後, 相対湿度 $20 \sim 40 \%$ まで緩や 


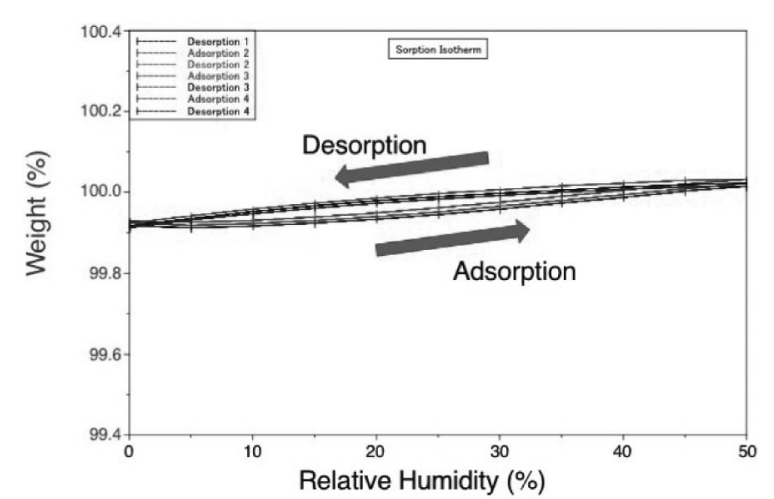

Fig. 3 Water sorption-desorption isotherm of the 5-Hydroxy-DL-Lysine monohydrochloride, generated at $25{ }^{\circ} \mathrm{C}$, relative humidity $0 \%$ to $50 \%$, using $\mathrm{N}_{2}$ as a carrier gas

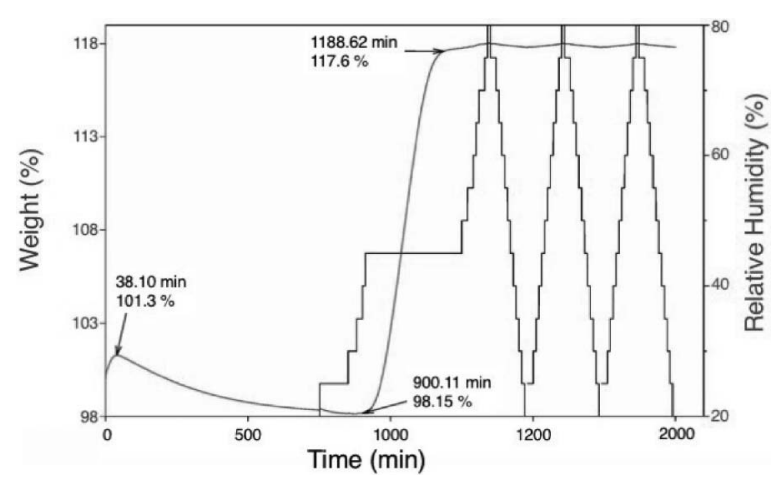

Fig. 4 Kinetics of the dynamic water sorptiondesorption of 3-Methyl-L-Histidine

かな質量減少が見られたが, その後相対湿度 $45 \%$ におい て急激な質量増大が見られ，2 サイクル目以降では安定し た質量変動を示した. 次に, 急激な質量増加を避けた条件 である相対湿度 0 〜 $40 \%$ の範囲について再測定を行った ところ, 低湿度領域で湿度変化をさせた場合でも質量が大 きく減少するという挙動が見られ, その減少挙動は測定ご とに異なり, 再現性の無いものであった. 一方, 高湿度環 境下に $3 \mathrm{MeHis}$ を暴露させることで十分に吸湿させると, 湿度変化に対する質量変動の再現性が高まることがわかっ た.このような現象は, $3 \mathrm{MeHis}$ が高湿度環境下で水和物 を形成し，その化学形態が変化したためであると推測され た. 吸湿時の質量変動から 1 分子当たり約 2 分子の水を含 む二水和物であると推定され, 定量 NMR 及び非水滴定法 から得られた純度 ${ }^{4)}$ から計算される值とも一致した。 そこ で，高湿度環境下において十分な吸湿処理を施すことによ り水和物を形成させた 3 -メチルヒスチジン二水和物 $\left(3 \mathrm{MeHis} \cdot 2 \mathrm{H}_{2} \mathrm{O}\right)$ を標準液の原料として用いることとし た. 水和物として作成した試料について再測定を行ったと ころ, 相対湿度 0〜 $50 \%$ で安定した挙動を示したため,

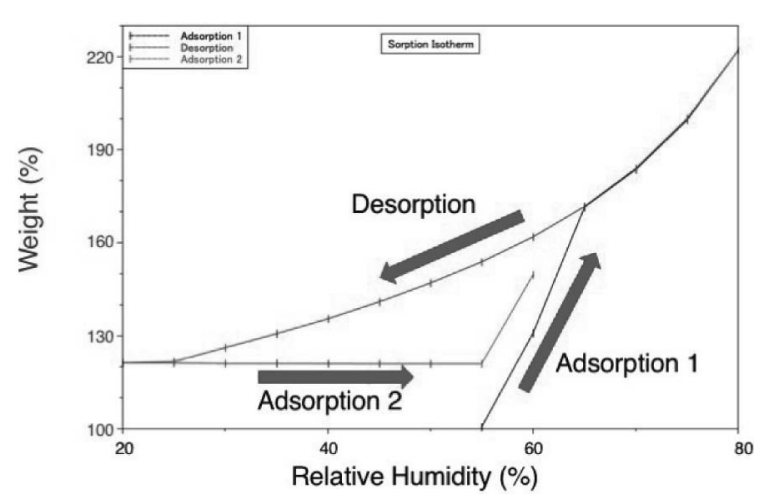

Fig. 5 Water sorption-desorption isotherm of Sarcosine, generated at $25{ }^{\circ} \mathrm{C}$, using $\mathrm{N}_{2}$ as a carrier gas

CRHを $50 \%$ とした.

また, Ansの場合にも相対湿度 0 〜 $80 \%$ における測定に おいて，3サイクル目で急激に質量が増大したまま安定す るという現象が観察された。この場合にも水和物を生成し ていることが予想されたが, $3 \mathrm{MeHis}$ の場合とは異なり, 吸 湿させる前の試料でも相対湿度 0〜 50\%において安定し た質量変動挙動を示したことから, CRH を 50 \% として水 和物ではないものを混合標準液の原料として用いることと した。

\section{$3 \cdot 3$ 湿度変化に対して非可逆的な質量変動が認められ} たアミノ酸類

前述のとおり，多くのアミノ酸類では脱湿により吸湿前 の質量に回復したが，一度吸湿すると容易には元の質量に 戻らない化合物も見られた。

特徵的な例として, Sarの例を挙げる.Sarでは相対湿度 $60 \%$ から急激な質量の増大が見られ, 最大で相対質量 $220 \%$ まで増大した。 また, 相対湿度 $20 \%$ まで湿度を下 げても相対質量 $120 \%$ までしか質量が減少せず, 2 サイク ル目の吸湿過程においても，相対湿度 $60 \%$ において再び 質量が急激に増大する様子が観測された（Fig. 5). そのた め, 急激な質量増大を示す前の相対湿度 $50 \%$ 以下の範囲 について再測定を行ったところ，この範囲での吸湿性の不 確かさはしきい值以内に収まった。また,このしきい值以 内の湿度範囲であれば脱湿により可逆的に元の質量まで戻 る様子も観測され, 安定した計量が可能であると考えられ たため, CRH を 50 \% とした. 同様の現象は, $\beta \mathrm{Ala}, 4 \mathrm{Abu}$ など 9 種類のアミノ酸類で見られたため, これらのアミノ 酸類を非可逆（I）と分類し，それぞれ CRH を設定した. このような挙動を示す物質は, 高湿度環境に一度暴露する と乾燥条件下に置かれても吸湿した水分が脱湿されず，容 易には元の質量に戻ることができない. そのため, 混合標 準液の調製に供する以前の保存環境に特に留意し, 常に 
CRH 以下の環境で管理する必要がある。

\section{$3 \cdot 4$ アミノ酸類混合標準液調製環境}

今回測定した 41 物質について, CRH ならびに質量変動 の可逆（R）もしくは非可逆（I）を Table 1 にまとめた. もっとも低い $\mathrm{CRH}$ を示したのは, Arg と MEA・Clの $40 \%$ であった。 また，この 2 物質は「非可逆（I）」であり，高 湿度環境下に曝露されることを強く避ける必要がある. そ のため作業時における一時的な湿度増大の可能性にも配慮 し, 混合標準液の調製環境としては相対湿度 $30 \%\left(25{ }^{\circ} \mathrm{C}\right)$ 以下を推奨する.

$$
4 \text { 結 言 }
$$

湿度制御機能付き熱重量測定装置を用いて, 41 種類の生 体関連アミノ酸類について吸湿性と昇華性の評価を行っ た.

$3 \mathrm{MeHis}$ のように, 水和物の形成により湿度に対する挙 動が変化することは想定内であったが, 類似した構造を持 つアミノ酸同士 (例えば, Ala と $\beta$ Ala, Abu, bAbu と 4Abu) でも吸湿挙動が大きく異なっており, 単純な化学構造から 吸湿性や昇華性を予想することは困難であることがわかっ た.このことは，湿度の変化に対する質量変動を実測する ことの必要性をより強く示している.

本報告により，湿度制御機能付き熱重量測定装置を用い た吸湿性評価は，アミノ酸混合標準液の精確な調製のため
の取り扱い環境を設定する上で，有効な手法であることが 確かめられた。 また，アミノ酸類以外の化合物においても 同様の評価が可能であることから，本法が様々な化合物に 対する吸湿性や昇華性の定量的な評価手段として広く利用 されることを期待する.

\section{謝辞}

本研究の一部は, 和光純薬工業株式会社からの受託研究 「トレーサビリティの確保された食品及び農薬関連標準物 質の供給に関する研究」において行われた。 ここに謝意を 表します。

$$
\left(\begin{array}{l}
\text { 平成 } 25 \text { 年 } 5 \text { 月 } 19 \text { 日, 第 } 73 \text { 回分 } \\
\text { 析化学討論会において, 一部発表 }
\end{array}\right)
$$

\section{文献}

1) Y. Miyagi, M. Higashiyama, A. Gochi, M. Akaike, T. Ishikawa, T. Miura, N. Saruki, T. Bando, H. Kimura, F. Imamura, M. Moriyama, I. Ikeda, A. Chiba, F. Oshita, A. Imaizumi, H. Yamamoto, H. Miyano, K. Horimoto, O. Tochikubo, T. Mitsushima, M. Yamakado, N. Okamoto : PloS One, 6, 2 (2011).

2) 井原俊英, 斎藤直樹, 加藤尚志, 加藤 愛, 山㟝太 一, 山中典子: アミノ酸研究 (Amino Acid Research), 8, 135 (2014).

3) 高津章子 : アミノ酸研究 (Amino Acid Research), 6 , 111 (2012).

4) 斎藤直樹, 齋藤 剛, 山﨑太一, 加藤尚志, 井原俊 英：分析化学 (Bunseki Kagaku), 63, 909 (2014). 


\title{
Evaluation of the Hygroscopicity of Amino Acids Reference Materials by Thermogravimetric Analysis
}

\author{
Hisashi Kato ${ }^{1}$, Xinnu BaO ${ }^{1}$, Akiko Suzuki ${ }^{1}$ and Toshihide IharA ${ }^{* 1}$ \\ * E-mail : t.ihara@aist.go.jp
}

\begin{abstract}
${ }^{1}$ National Metrology of Japan, National institute of Advanced Industrial Science and Technology, 1-1-1, Umezono, Tsukuba-shi, Ibaraki 305-8563
\end{abstract}

(Received September 12, 2016; Accepted December 16, 2016)

\begin{abstract}
Amino acids are essential nutriments and the most basic construct matter of a living organisms. Thus, the amino acid content is determined in various fields. However, reference materials are necessary for making calibration curves for quantitative analysis, such as chromatography methods. Therefore, a variety of amino acids standard solution that is traceable to the International System of Units (SI) have a wide field of demand. To make standards solution of the precise concentration, which requires reference materials with accurate purity and precise weighing methods. However, for precise weighing, an appropriate weighing environment is neccessary. It was known that to some amino acids have strong hygroscopicity, but it wasn't known in a quantitative form. Therefore, previously weighing environment is empirically-determined. We measured the hygroscopicity of amino acids for deciding on a quantitatively-assessed weighing environment to obtain a precise amount of amino acids, and to prepare a standard solution with precise concentrations. We estimated the hygroscopicity and sublimability of 41 amino acids using temperature and humiditycontrolled thermobalance equipment. As a result, when it was below a relative humidity $30 \%$ (at $25^{\circ} \mathrm{C}$ ), we can weigh a precise amount of 41 amino acids. We can prepare an amino acids standard solution with precise concentrations. We create a methodology for determining a quantitatively-assessed weighing environment to obtain the precise mass or concentration of the standard solution. This methodology is effective and it can be applied widely.
\end{abstract}

Keywords: amino acids; reference material; hygroscopicity; sublimability; standard solution. 